\title{
UI EFEKTIVITAS AIR PERASAN JERUK NIPIS (CITRUS AURANTIFOLIA) DAN AIR JERUK LEMON (CITRUS LIMON) DALAM MENGHAMBAT PERTUMBUHAN JAMUR CANDIDA ALBICANS
}

\author{
Windy Claudia Lubis ${ }^{1}$, Elisabet Tampubolon ${ }^{2}$, Ali Napiah Nasution ${ }^{3}$, Riyani Susan Bt. Hasan ${ }^{4}$ \\ 1,2, Program Studi Pendidikan Dokter, Fakultas Kedokteran, Universitas Prima Indonesia \\ ${ }^{3}$ Kedokteran Tropis, , Fakultas Kedokteran, Universitas Prima Indonesia \\ ${ }^{4}$ Mikrobiologi, , Fakultas Kedokteran, Universitas Prima Indonesia \\ riyanisusan@yahoo.com
}

\begin{abstract}
Abstrak
Mayoritas masyarakat Indonesia menggunakan bahan-bahan alami untuk melakukan pengobatan, seperti jeruk nipis dan jeruk lemon dikarenakan mudah ditemukan. Masyarakat biasa menggunakannya untuk meredakan batuk,influenza,sakit tenggorokan, menurunkan demam,hingga kandidiasis atau biasa diketahui sariawan. Kandidiasis adalah suatu infeksi yang ada pada kulit maupun juga pada selaput lendir dimana disebabkan akibat jamur dari jenis candida tetapi paling sering disebabkan oleh candida albicans. Penelitian yang dilakukan menggunakan desain eksperimental memakai metode dari difusi cakram. Berlandaskan data dari pengujian sudah dilakukan menyatakan adanya pengaruh pada air perasan jeruk nipis pada perkembangan jamur Candida Albicans dari konsentrasi 25\% (10,26 mm),50\% (14,53 mm),75\% (16,96 $\mathrm{mm}$ ), dan 100\% (18.06 mm). Dari semua konsentrasi air perasan jeruk nipis yang telah di uji,konsentrasi $100 \%(18,06 \mathrm{~mm})$ memiliki daya hambat yang paling tinggi dan konsentrasi $25 \%(10,26 \mathrm{~mm})$ merupakan daya hambat minimum terhadap pertumbuhan candida albicans. Untuk hasil pengujian air perasan jeruk lemon menunujukkan bahwa terhadap pengaruh air perasan jeruk lemon terhadap pertumbuhann jamur Candida Albicans dari konsentrasi 25\% (12,83 mm),50\% (15,1 mm),75\% (16,7 mm),dan 100\% (19.36). Dari semua konsentrasi air perasan jeruk lemon yang telah di uji , konsentrasi $100 \%(19,36)$ memiliki daya hambat yang paling tinggi dan konsentrasi $25 \%(12,83 \mathrm{~mm})$ merupakan daya hambat minimum terhadap pertumbuhan candida albicans. Untuk kontrol positif menggunakan ketoconazole $2 \%(22,16 \mathrm{~mm})$ dimana memiliki efek yang lebih tinggi untuk menghambat perkembangan jamur candida albicans. Berlandaskan dari penelitian sudah dilakukan bisa ditarik kesimpulan bahwa adanya efek dalam menurunkan pertumbuhan dari air perasan jeruk nipis juga jeruk lemon untuk pertumbuhan Candida Albicans.
\end{abstract}

Kata kunci : Perasan jeruk nipis dan lemon , candida albicans, Kandidiasis

\begin{abstract}
The majority of Indonesians use natural ingredients for treatment, such as lime and lemon because they are easy to find. Ordinary people use it to relieve coughs, influenza, sore throat, reduce fever, to candidiasis or canker sores are commonly known. Candidiasis is an infection that is on the skin and also on the mucous membrane which is caused by a fungal type of candida but is most often caused by candida albicans. The research was conducted using an experimental design using the method of disc diffusion. Based on the data from the test has done already, it states there's an effect from lime juice on the development of Candida Albicans fungi from a concentration of $25 \%(10.26 \mathrm{~mm}), 50 \%(14.53 \mathrm{~mm}), 75 \%(16.96 \mathrm{~mm})$, and $100 \%(18.06)$. $\mathrm{mm})$. Of all the concentrations of lime juice that have been tested, the concentration of $100 \%(18.06 \mathrm{~mm})$ has the highest inhibitory power and the concentration of $25 \%(10.26 \mathrm{~mm})$ is the minimum inhibitory power against sprouting by candida albicans. Test results by lemon juice showed that the effect of lemon juice on the growth of Candida Albicans fungi from a concentration of $25 \%(12.83 \mathrm{~mm}), 50 \%(15.1 \mathrm{~mm}), 75 \%(16.7 \mathrm{~mm})$, and $100 \%$ (19.36). Of all the concentrations of lemon juice that have been tested, the concentration of $100 \%$ (19.36) has the highest inhibitory power and the concentration of $25 \%(12.83 \mathrm{~mm})$ is the minimum inhibitory power against the growth of candida albicans. For positive control using ketoconazole $2 \%(22.16 \mathrm{~mm})$ which has a higher effect on inhibiting the development of the fungus candida albicans. Build upon the research done, it could be able concluded there's an inhibition zone in lime juice and lemon juice for the growth of Candida albicans.
\end{abstract}

Keywords: lime juice and lemon juice (citrus limon), candida albicans, candidiasis 


\section{PENDAHULUAN}

Rata-rata masyarakat kita yakni Indonesia semenjak dulu memakai tanaman sebagai obat untuk mencegah berbagai masalah kesehatan. Masalah yang kerap menimpa penduduk Indonesia adalah penyakit Kandidiasis yang diakibatkan oleh beberapa jamur diantaranya Candida Albicans. ${ }^{1}$

Di seluruh tubuh kita hampir memiliki jamur Candida Albicans diantaranya adalah daerah mukosa mulut, saluran cerna,kulit. Candida Albicans adalah salah satu flora normal yang berada dalam tubuh manusia, namun jika jumlah nya berlebih dapat berakibat menjadi patogen. ${ }^{2}$

Jamur Candida Albicans dapat berkembang dengan baik di daerah yang lembab dan juga dapat menyesuaikan diri dengan daerahnya sehingga dapat ditemukan di semua daerah di seluruh dunia. ${ }^{3}$ Candida Albicans adalah mikroorganisme yang merupakan dari kelompok yeast dan golongan dari deuteromycota, berkembang secara aseksual dan juga termasuk jamur dimorfik. ${ }^{4}$

Tumbuhan yang bisa digunakan untuk obat tradisional dapat berupa sayur-sayuran, buah, tanaman liar yang tumbuh disembarang tempat, bumbu dapur. Diantara tanaman dan buah yang bisa digunakan untuk obat tradisional adalah jeruk nipis juga jeruk lemon. Penduduk Indonesia sejak dulu memakai tanaman sebagai obat untuk mencegah berbagai masalah kesehatan. Masalah yang kerap menimpa penduduk Indonesia adalah penyakit Kandidiasis yang diakibatkan oleh beberapa jamur diantaranya Candida Albicans. ${ }^{5}$

Sitrus atau biasa kita ketahui sebagai jeruk merupakan salah satu tanaman atau buah yang mempunyai kandungan vitamin $\mathrm{C}$. Terkandung beberapa senyawa bioaktif yakni saponin, steroid, minyak atsiri, flavonoid pada jeruk. Ada beberapa bahan aktif baik untuk kesehatan yang ada di jeruk yaitu vitamin C, saponin, flavonoid, limonoid, karotenoid, serta mineral. Sebab di dalam buah jeruk terdapat kandungan fenolik, buah jeruk bisa dimanfaatkan untuk antibakteri, antifungi, antiinflamasi. ${ }^{6}$

Dapat diamati bahwa jeruk nipis dan jeruk lemon selalu dipakai oleh masyarakat pada pengobatan atau pencegahan untuk batuk, influenza, penurun rasa panas, sariawan, radang tenggorokan mengobati jerawat dan juga dugunakan sebagai penambah nafsu makan. ${ }^{7}$

\section{METODE}

Desain penelitian yang digunakan adalah eksperimental laboratorium Waktu dan tempat dilakukannya penelitian ini adalah pada Mei hingga Juli 2020 berlokasi di laboratorium Mikrobiologi Fakultas Kedokteran Universitas Prima Indonesia.

Tabung reaksi, Autoclave, spektrofoto-meter, mikropipet, pengukuran waktu, Timbangan, Bunsen, Cakram uji kosong, Alat tulis, Kamera, Cawan petri (petri dish), pinset, Ose, Korek api, Jangka sorong, Tabung Erlenmeyer, merupakan alat-alat yang digunakan dalam penelitian ini dan perasan air dari jeruk nipis \& jeruk lemon, Biakan Jamur Candida Albicans, Potato Dextrose Agar (PDA), $\mathrm{NaCl} \mathrm{0,9 \% ,}$ Cotton swab steril, Aluminium foil, Kertas saring, Tisu merupakan bahan bahan yang di gunakan dalam penelitian ini.

Konsentrasi air perasan jeruk nipis dan jeruk lemon yang dipakai yaitu 25,50,75,dan $100 \%$. Untuk mendapatkan masing-masing konsentrasi, maka dilakukan dengan metode volume per volume (v/v) dengan menggunakan bahan pelarut aquadest steril .Dewi, K. E. K. (2019).

Pembuatan Media Potato Dextrose Agar, Siapkan alat yang sudah dilakukan pensterilan. Menimbang media PDA sesuai dengan aturan dan kebutuhan. Masukkan kedalam beaker glass dilarutkan dengan aquades lalu panaskan diatas hot plate dan aduk sampai mendidih selama kurang lebih 10 menit.

Masukkan media tersebut kedalam erlenmayer kemudian tutup menggunakan kapas dan aluminium, lalu sterilisasi kan kedalam autoclave pada suhu $121^{\circ} \mathrm{C}$ dalam waktu kurang lebih 15 menit. Biarkan dingin lalu simpan kedalam refrigenerator untuk disimpan.

Pembuatan Suspensi Jamur Candida Ablicans, Siapkan alat dan bahan yang sudah dilakukan sterilisasi , Kemudian ambil satu ose yang ber-isolat dari jamur yang digunakan yakni candida albicans masukkan pada tabung berisi $1 \mathrm{ml}$ aquades,lalu homogenkan.

Prosedur Pemeriksaan Anti Jamur, Siapkan alat dan bahan yang telah dilakukan sterilisasi. Siapkan cakram disk kosong dan diteteskan $20 \mu \mathrm{L}$ perasan buah jeruk nipis dan juga jeruk lemon pada 
setiap konsentrasi hingga seluruh cairan dapat meresap. Siapkan suspense jamur candida albicans. Siapkan cotton swab steril dan celupkan ke dalam suspense yang di sediakan. Lakukan inokulasi pada media Potato Dextrose Agar (PDA) pada seluruh permukaannya secara merata. Diamkan selama 15 menit.

Perasan air jeruk nipis dan jeruk lemon yang telah ditentukan konsentrasi nya dapat dilakukan penempelan pada media tersebut, begitu pula dengan kontrol positif dan negatif yang akan digunakan. Lapisi cawan petri yang telah diguanakan dengan plastic wrap, agar tetap rapi. Masukkan cawan petri kedalam deksikator di suhu $25-27^{\circ} \mathrm{C}$ selama 2-3 hari. Lihat serta amati pertumbuhan dari koloni tersebut lalu dokumentasikan.

\section{HASIL}

Hasil Pengujian Anti Jamur

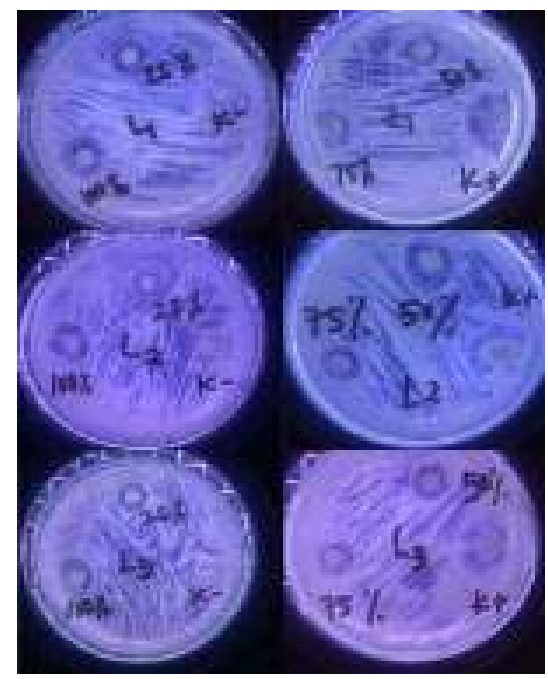

Gambar 1. Zona bening pada Jamur yang diberi perasan jeruk nipis.

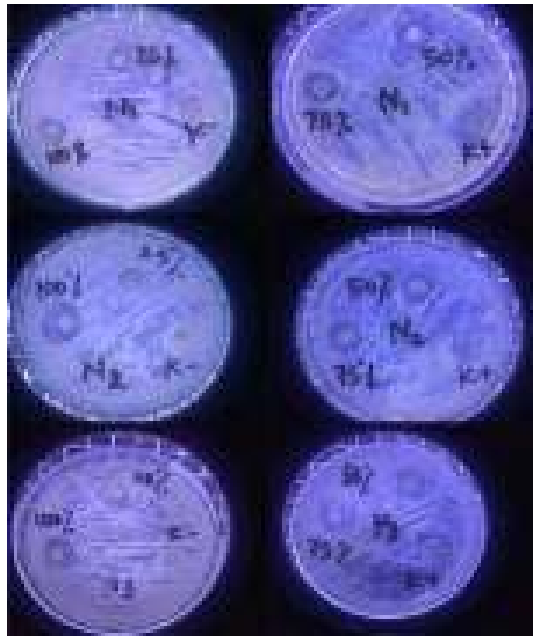

Gambar 2. Zona bening pada Jamur yang diberi perasan jeruk lemon.

Perbandingan Diameter Zona Hambat Ekstrak Perasan Air Jeruk Nipis Untuk Mengurangi Pertumbuhan Jamur Candida ablicans

Tabel 1. Tabel Pada Jamur Diberi Air Perasan Jeruk Nipis

\begin{tabular}{cccccc}
\hline No. & Kons. & $\begin{array}{c}\text { D1 } \\
\text { (mm) }\end{array}$ & $\begin{array}{c}\text { D2 } \\
\text { (mm) }\end{array}$ & $\begin{array}{c}\text { D3 } \\
\text { (mm) }\end{array}$ & $\begin{array}{c}\text { Kriteria } \\
\text { Hambatan }\end{array}$ \\
\hline 1 & $25 \%$ & 9,7 & 10,1 & 11,0 & $8,83 \mathrm{~mm}$ \\
\hline 2 & $50 \%$ & 13,2 & 14,4 & 16,0 & $14,53 \mathrm{~mm}$ \\
\hline 3 & $70 \%$ & 14,4 & 17,6 & 18,9 & $16,96 \mathrm{~mm}$ \\
\hline 4 & $100 \%$ & 16,0 & 18,2 & 20,0 & $18,06 \mathrm{~mm}$ \\
\hline
\end{tabular}

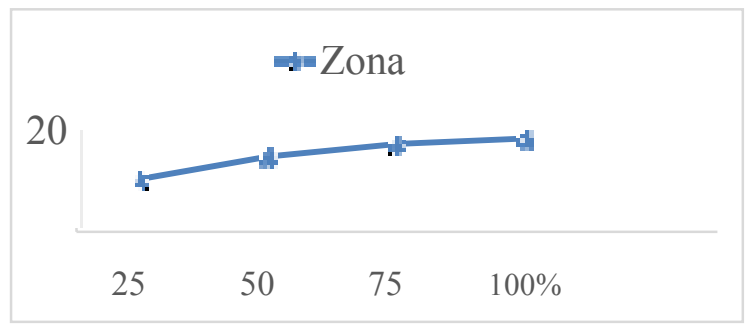

Gambar 3. Grafik Pada Bakteri Diberi Perasan Jeruk Nipis

Dari tabel 1. dan gambar 3. diatas dapat dilihat bahwa timbul peningkatan di zona hambat Candida Albicans dalam air perasan jeruk nipis untuk konsentrasi yakni $25 \%(10,26 \mathrm{~mm}), 50 \%$ 
$(14,53 \mathrm{~mm}), 75 \%(16,96 \mathrm{~mm})$, dan $100 \%$ (18.06).

Perbandingan Diameter Zona Hambat Ekstrak Air Perasan Jeruk Lemon Dalam Menghambat Pertumbuhan Jamur Candida ablicans

Tabel 2. Tabel Pada Jamur Diberi Air Perasan Jeruk Lemon

\begin{tabular}{cccccc}
\hline No. & Kons. & $\begin{array}{c}\text { D1 } \\
\text { (mm) }\end{array}$ & $\begin{array}{c}\text { D2 } \\
\text { (mm) }\end{array}$ & $\begin{array}{c}\text { D3 } \\
\text { (mm) }\end{array}$ & $\begin{array}{c}\text { Kriteria } \\
\text { Hambatan }\end{array}$ \\
\hline 1 & $25 \%$ & 13,2 & 12,2 & 13,1 & $12,83 \mathrm{~mm}$ \\
\hline 2 & $50 \%$ & 14,0 & 15,1 & 16,2 & $15,1 \mathrm{~mm}$ \\
\hline 3 & $70 \%$ & 17,5 & 16,6 & 16,0 & $16,7 \mathrm{~mm}$ \\
\hline 4 & $100 \%$ & 20,0 & 18,5 & 19,6 & $19,36 \mathrm{~mm}$ \\
\hline
\end{tabular}

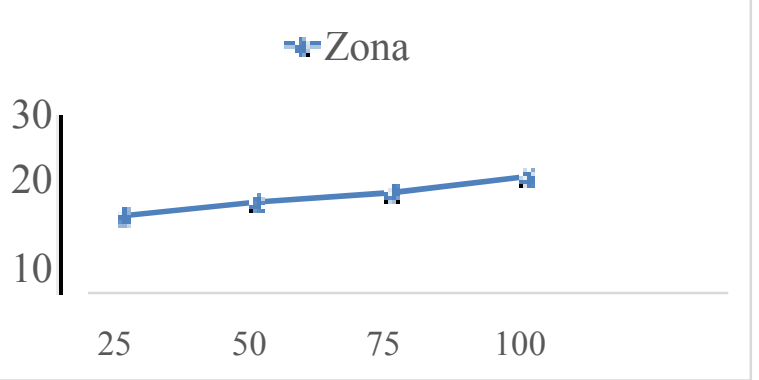

Gambar 4. Grafik Pada Jamur Diberi Perasan Jeruk Lemon

Dari tabel 2. Dan gambar 4. Diatas dapat dilihat bahwa adanya peningkatan pada zona hambat untuk Candida Albicans pada air perasan jeruk lemon dimana konsentrasi 25\% (12,83mm), $50 \%(15,1 \mathrm{~mm}), 75 \%(16,7 \mathrm{~mm})$, dan $100 \%$ (19.36).

\section{Konsentrasi Hambat Minimum (KHM)}

Pengujian ini dilaksanakan sesudah mendapatkan hasil dari konsentrasi terendah dari pengujian yang telah dilakukan dalam menghambat jamur. Pengujian ini dilaksanakan untuk melihat konsentrasi air perasan jeruk nipis dan jeruk lemon paling terendah dan bisa menghambat perkembangan jamur. Konsentrasi air perasan jeruk nipis juga jeruk lemon yang dipakai yaitu $25 \%$ dan $50 \%$. Hasilnya setelah inkubasi selama 24 jam.

Tabel 3. Tabel KHM

\begin{tabular}{cccc}
\hline No. & Kons. JN & Kons. JL & \multicolumn{1}{c}{ Ket } \\
\hline 1 & $25 \%$ & $25 \%$ & $\begin{array}{l}\text { Terdapat zona } \\
\text { hambat dengan } \\
\text { terbentuknya } \\
\text { zona bening. }\end{array}$ \\
\hline
\end{tabular}

Konsentrasi Hambat Minimum (KHM) pada air perasan jeruk nipis dan jeruk lemon yang digunakan yaitu $25 \%$ dengan memiliki hambatan yang dihasilkan jeruk nipis $(10,26 \mathrm{~mm})$ dan jeruk lemon $(12,83)$.

\section{Konsentrasi Bunuh Minimum (KBM)}

Pengujian ini berguna untuk melihat seberapa besar konsentrasi antijamur yang bisa membunuh jamur. Pengujian KBM dilakukan dengan menggunakan konsentrasi terendah yaitu $25 \%$ dan $50 \%$ dalam uji KHM dan tidak ditumbuhi jamur (zona bening).

\begin{tabular}{|c|c|c|}
\hline Kons. & Interpretasi JN & Interpretasi JL \\
\hline $25 \%$ & $\begin{array}{lr}\text { Terdapat } & \text { zona } \\
\text { bening } & \text { dengan } \\
\text { diameter } & 11,0 \mathrm{~mm}\end{array}$ & $\begin{array}{l}\text { Terdapat zona } \\
\text { bening dengan } \\
\text { diameter } 13,1 \\
\mathrm{~mm}\end{array}$ \\
\hline $50 \%$ & $\begin{array}{lr}\text { Terdapat } & \text { zona } \\
\text { bening } & \text { dengan } \\
\text { diameter } & 16,0 \mathrm{~mm}\end{array}$ & $\begin{array}{l}\text { Terdapat zona } \\
\text { bening dengan } \\
\text { diameter } 16,2 \\
\mathrm{~mm}\end{array}$ \\
\hline
\end{tabular}

\section{Uji Oneway Anova}

Dari hasil uji statistika yang dilakukan pada kedua ekstrak menggunakan uji oneway anova didapati nilai signifikannya $=0,000$, hal ini mengartikan bahwa nilai signifikansi $<\alpha=0,05$, yaitu didapat dengan volume yang berbeda-beda pada jeruk lemon maupun jeruk nipis, perasannya dengan memiliki pengaruh kepada pertumbuhan Jamur Candida ablicans. Sehingga pengujian hipotesa dapat disimpulkan bahwa h0 ditolak dan ha diterima "Ada pengaruh pemberian air perasan jeruk lemon dan jeruk nipis terhadap perkembangan Jamur Candida ablicans".

\section{DISKUSI}

Aktivitas antijamur pada air perasan jeruk nipis bisa dilihat yakni dengan mengukur diameter zona hambat dimana sudah terwujud di Media Potato Dextrose Agar (PDA). Berlandaskan data yang sudah didapat diketahui jika air perasan jeruk nipis mempunyai kemampuan untuk menurunkan kuantitas jamur Candida Albicans dengan menghambat perkembangan jamur. ${ }^{8}$ Berlandaskan hasil dari penelitian didapati adanya beragam diameter zona hambat dimana terjadi akibat beda 
nya konsentrasi air perasan jeruk nipis. Dimana jika konsentrasi dari air perasan jeruk nipis tinggi serta diameter dari zona hambat semakin besar dan besar pula kemampuan hambatan yang didapatkan. ${ }^{9}$ Berikut memperlihatkan jika menaiknya konsentrasi dari air perasan jeruk nipis besar pula isi dari bahan aktif yang terkandung di air perasan jeruk nipis dimana berguna untuk antijamur, maka besar pula kemampuan untuk menghambat perkembangan jamur.

Hasil untuk penelitian tersebut sesuai pada penelitian Iskandar Yosia Dkk, 2017 dengan judul yakni perbandingan efektivitas air perasan jeruk nipis serta ketokonazol $2 \%$ selaku antijamur untuk malassezia furfur yakni dengan in vitro didapatkan kesimpulan bahwa perbandingan dari efektivitas air perasan jeruk nipis memakai konsentrasi $100 \%$ serta ketokonazol $2 \%$ selaku antijamur untuk Malassezia furfur dengan in vitro yaitu setara. Air perasan jeruk nipis volume/konsentrasi $100 \%$ juga ketokonazol terbukti efektif selaku antijamur untuk Malassezia furfur. ${ }^{10}$

Aktivitas antijamur air perasan jeruk lemon bisa didapatkan yaitu lewat menghitung diameter zona hambat dimana telah terwujud di media Potato Dextrose Agar (PDA). Berlandaskan hasil dapat dilihat jika air perasan jeruk lemon memiliki kesanggupan untuk menyurutkan perkembangan jamur Candida Albicans. Berlandaskan data pada penelitian didapati adanya variasi diameter zona hambat dimana terjadi karena beda konsentrasi untuk perasan jeruk lemon. Dimana jika volume/konsentrasi dari air perasan jeruk lemon tinggi lalu diameter dari zona hambat semakin besar maka besar pula kemampuan untuk menghambat. Berikut memperlihatkan jika meningkatnya konsentrasi dari air perasan jeruk lemon, besar pula isi dari bahan aktif yang terdapat di air perasan jeruk lemon dimana berguna untuk antijamur, maka besar pula kemampuan untuk menghambat perkembangan jamur.

Hasil pada penelitian tersebut sesuai pada penelitian Razakilahi Margono Dkk 2016 dengan judul uji daya hambat air perasan buah lemon cui (citrus microcarpabunge) pada perkembangam candida albicans dimana diisolasi pada plat gigi tiruan lepasan akrilik hal ini memperlihat jika nilai yang didapat pada air perasan buah lemon cui sebanyak 8,42 mm. Berikut dikarenakan senyawa di air perasan pada buah lemon cui yaitu asam sitrat juga vitamin C bisa menghalangi perkembangan Candida albicans dimana diisolasi untuk plat gigi tiruan lepasan akrilik, tetapi zona hambat didapat lebih sedikit daripada obat ketokonazol.

Flavonoid merupakan senyawa fenol dimana mempunyai 15 atom karbon dimana terdiri pada konfigurasi C6-C3-C6 (dua cincin aromatik yang terjalin pada tiga karbon dimana bisa ataupun tidak bisa menjadi cincin tiga). Gugus hidroksil (-H) nyaris kerap ada pada flavonoid, yang mana gugus dari hidroksil merupakan letak merekatnya bermacam jenis gula dimana dapat berdampak terhadap kelarutan flavonoid pada air. Senyawa fenol, mempunyai sifat yang efektif untuk menghambat perkembangan virus, bakteri maupun jamur. ${ }^{11}$ Mekanisme pada flavonoid untuk menghambat jamur dapat bekerja yaitu dengan denaturasi protein mengait permeabilitas pada membran sel. Denaturasi protein mengakibatkan hambatan pada pembuatan sel, lalu mengganti komposisi pada komponen protein, dimana mengakibatkan hambatan pada membrane sel bisa mengakibatkan kenaikan permeabilitas dari sel tersebut dimana dapat mengakibatkan rusaknya sel di jamur. Kerusakan dapat mengakibatkan kematian untuk sel jamur. ${ }^{12}$ Aktivitas untuk antijamur pada minyak atsiri tergantung di komposisi juga konsentrasi pada minyak atsiri serta pada tipe maupun banyaknya dari mikroorganisme target. Minyak atsiri bisa menghalangi proses dari terbentuknya membran sel jamur maupun dinding dari sel jamur, mengakibatkan membran juga dinding sel jamur tidak bisa terbentuk sempurna. ${ }^{13}$

\section{PENUTUP}

1. Berlandaskan data diatas memperlihatkan terdapat pengaruh air perasan jeruk nipis terhadap pertumbuhan jamur Candida Albicans dari konsentrasi $25 \%(10,26 \mathrm{~mm}), 50 \%(14,53$ $\mathrm{mm}), 75 \%$ (16,96 mm), dan 100\% (18.06).

2. Berdasarkan hasil diatas menunjukkan bahwa terdapat pengaruh air perasan jeruk lemon terhadap pertumbuhann jamur Candida Albicans dari konsentrasi $25 \%(12,83 \mathrm{~mm}), 50 \%(15,1$ $\mathrm{mm}), 75 \%(16,7 \mathrm{~mm})$, dan $100 \%$ (19.36). 
3. Konsentrasi Hambat Minimum (KHM) pada air perasan jeruk nipis dan jeruk lemon yang digunakan yaitu $25 \%$ dengan memiliki hambatan yang dihasilkan jeruk nipis $(10,26 \mathrm{~mm})$ dan jeruk lemon $(12,83)$

4. Konsentrasi Hambat Minimum (KHM) pada air perasan jeruk nipis dan jeruk lemon yang digunakan yaitu $25 \%$ dengan memiliki hambatan yang dihasilkan jeruk nipis $(10,26 \mathrm{~mm})$ dan jeruk lemon $(12,83)$

5. Berdasarkan hasil diatas menunjukkan bahwa air perasan jeruk Lemon lebih baik ketimbang air perasan jeruk Nipis dalam menghambat perkembangan jamur Candida Albicans. Dikarenakan konsentrasi pada air perasan jeruk lemon terhadap kenaikan diameter zona hambat jamur Candida Albicans sebanyak 91,9\%, sedangkan konsentrasi untuk air perasan jeruk nipis atas kenaikan diameter untuk zona hambat yakni jamur Candida Albicans 76,3\%.

\section{SARAN}

1. Disarankan kepada penelitian berikutnya lebih berhati-hati dalam membiakan jamur, mencoba mengganti tingkat konsentrasi air perasan.

2. Perlu dilaksanakan penelitian lanjutan untuk melihat efektifitas jeruk nipis dan lemon dalam menghambat jamur lain.

\section{DAFTAR PUSTAKA}

1. Dwiyanti, R. D., Nailah, H., Muhlisin, A., \& Lutpiatina, L. (2018). Efektivitas Air Perasan Jeruk Nipis (Citrus aurantifolia) dalam Menghambat Pertumbuhan Escherichia coli. Jurnal Skala Kesehatan, 9(2), 1-7.

2. HIDAYAT, TIASMARA. DAYA HAMBAT MINYAK ATSIRI KULIT BUAH JERUK NIPIS (Citrus aurantifolia S) MERK" $X^{\prime \prime}$ TERHADAP Pityrosporum ovale SECARA IN VITRO. Diss. STIKes BTH Tasikmalaya, 2018.

3. Janik, et al ;James ; C. ; R. (2016). Pengertian Kandidiasis. 7-21.

4. Silvia, D. (2018). Uji Aktivitas Antifungi Ekstrak Kulit Buah Jeruk Nipis (Citrus aurantifolia) Terhadap Jamur Candida albicans. Universitas Islam Negeri Sunan Ampel, 57-84.
5. Musiam, Siska, et al. "AKTIVITAS ANTIFUNGI FLAVONOID DARI EKSTRAK DAUN Citrus aurantifolia KALIMANTAN SELATAN TERHADAP PERTUMBUHAN Candida albicans." AFAMEDIS 1.1 (2020): 55-63.

6. Anonim. (2017). Tinjauan Pustaka Jeruk Nipis. Jeruk Nipis (Citrus Aurantifolia, Swingle, Gambar 1, 8-31. http://ejournal.uajy.ac.id/14221/3/BL013332.pdf

7. Diisolasi, Y., Plat, D., Tiruan, G., \& Akrilik, L. (2016). UJI DAYAHAMBAT AIR PERASAN BUAH LEMON CUI ( Citrus microcarpa Bunge) TERHADAP PERTUMBUHAN Candida albicans. 5(3).

8. Hidayah, A. N. (2010). Efektivitas (Citrus limon BURM ) $25 \%$ Dibandingkan $2 \%$ Terhadap Pertumbuhan Malassezia sp. Pada Ketombe

9. Hartin, E., \& Rini, C. S. (2019). Efektivitas Jeruk Lemon (Citrus limon Linn) terhadap Staphylococcus epidermidis. Journal of Medical Laboratory Science Technology, 2(1), 6-9. https://doi.org/10.21070/medicra.v2i1.1617

10. Iskandar, Y., Soejoto, B. S., \& Hadi, P. (2017). Perbandingan Efektivitas Air Perasan Jeruk Nipis (Citrus Aurantifolia Swingle) Dengan Ketokonazol 2\% Sebagai Antijamur Malassezia Furfur Secara in Vitro. Diponegoro Medical Journal (Jurnal Kedokteran Diponegoro), 6(2), 1394-1401.

11. Sekunder, M. (n.d.). PERBANDINGANAKTIVITAS ANTIFUNGI AIR PERASAN JERUK NIPIS (Citrus aurantifolia ), JERUK PURUT (Citrus hystrix) DAN JERUK LEMON (Citrus Limon ) TERHADAP Candida albicans COMPARISON OF THE ANTIFUNGAL ACTIVITY OF LIME JUICE (Citrus aurantifolia ), KAFFIR. 1-7.

12. Nurlaely, E. (2016). UJI EFEKTIVITAS AIR PERASAN JERUK LEMON ( Citrus Limon ( $L$.) Burm . $f$. ) TERHADAP BAKTERI STAPHYLOCOCCUS. Karya Tulis IImiah, 1-19.

13. Maimunah, Endang. UJI EFEKTIVITAS AIR BUAH JERUK NIPIS (Citrus aurantifolia) DALAM MENGHAMBAT Candida albicans (Studi di STIKes ICMe Jombang). Diss. STIKES Insan Cendekia Medika Jombang, 2018. 
Jurnal Ilmiah Mahasiswa Kesehatan Masyarakat Vol. 5/No. 4/Oktober 2020; ISSN: 2502-731X 